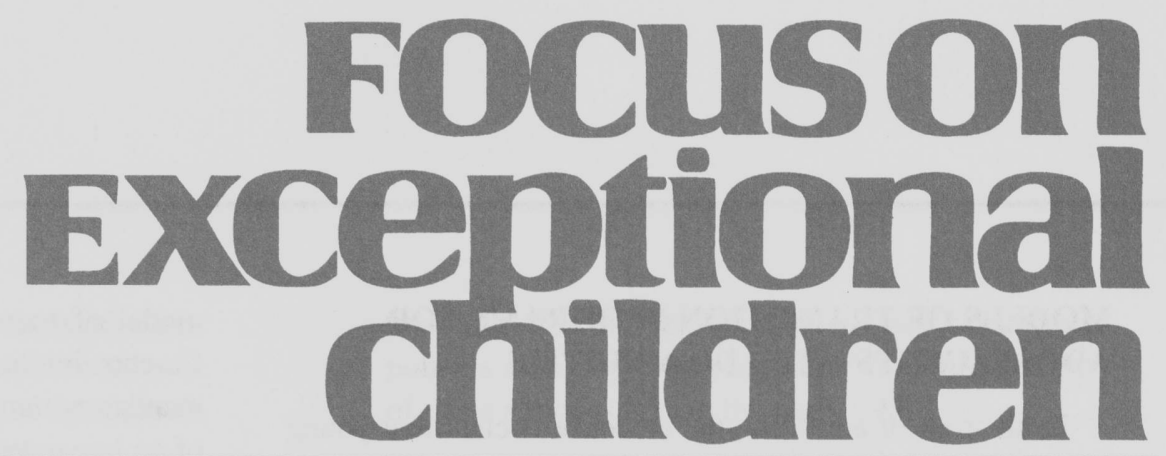

\title{
Using Successful Models of Student-Centered Transition Planning and Services for Adolescents with Disabilities
}

\author{
Mary E. Morningstar, P. Jeannie Kleinhammer-Tramill, and Dana L. Lattin
}

In its most basic context the term transition means change, or "a passing from one condition or place to another" (Webster's New World Dictionary, p. 635). Transitions from one life stage to another occur throughout one's life and are characterized as times of stress, conflict, redefinition, and sometimes dysfunction (Carter \& McGoldrick, 1980; Clark \& Kolstoe, 1995, Turnbull, Summers, \& Brotherson, 1986). In special education, transition is used to describe a systematic passage from school to adult life for students with disabilities. In this sense, transition is seen as a bridge between the security of school and home and the risks and opportunities of adult life (Will, 1984). All adolescents experience the stresses and adjustments related to this transition. Those with disabilities, however, often experience more significant difficulties (Peraino, 1993).

One common denominator among adolescents with disabilities making the transition from school to adult life is that they could be considered to have complex support needs, especially in finding and sustaining employment, living independently, and attaining postsecondary education and training. In fact, a unique aspect of school-based transition planning and services is the movement away from traditional categorical approaches in providing special education and making the transition from school to adult life. Secondary special education professionals no longer have to categorize services by the type or nature of the disabilities but, instead, can focus on the student's desired postschool outcomes, take into account the student's strengths and interests, and develop transition plans that meet these unique support needs.

This article will trace the history of transition programs for adolescents with disabilities and the role that transition plays within current reform efforts. Information regarding current best practices will be discussed. Finally, we will provide strategies for infusing state-of-art practices within school programs.

The authors are affiliated with the University of Kansas. 


\section{MODELS OF TRANSITION PROGRAMS FOR ADOLESCENTS WITH DISABILITIES}

In all areas of adult life, the evidence is clear that young adults with disabilities do not fare as well as their peers without disabilities. Students with disabilities have significantly higher drop-out rates (CEC, 1994), lower employment rates (Blackorby \& Wagner, 1996), lower rates of independent living (Kiernan, McGaughey, Lynch, Morganstern, \& Schalock, 1991); and they do not pursue college or postsecondary education (Blackorby \& Wagner, 1996). Yet, a focus on the economic and educational difficulties that youth with disabilities face is not new. "Transition services" for youth with disabilities could be found as early as the 1930s for deaf students, and the 1940s for students with mental retardation (Rusch, Szymanski, \& Chadsey-Rusch, 1992).

Not until the 1960s, however, were educational and vocational models developed to comprehensively address the dimensions of adult adjustment. Early efforts included (a) cooperative workstudy programs, (b) career education, (c) OSERS "bridge" model of transition, (d) Halpern's revised

\section{FOCuson Exceptional children}

ISSN 0015-511X FOCUS ON EXCEPTIONAL CHILDREN (USPS 203-360) is published monthly except June, July, and August as a service to teachers, special educators, curriculum specialists, administrators, and those concerned with the special education of exceptional children. This publication is annotated and indexed by the ERIC Clearinghouse on Handicapped and Gifted children for publication in the monthly Current Index to Journals in Education (CIJE) and the quarterly index, Exceptional Children Education Resources (ECER). The full text of Focus on Exceptional Children is also available in the electronic versions of the Education Index. It is also available in microfilm from Xerox University Microfilms, Ann Arbor, MI. Subscription rates: Individual, \$30 per year; institutions, \$40 per year. Copyright (C) 1999, Love Publishing Company. All rights reserved. Reproduction in whole or part without written permission is prohibited. Printed in the United States of America. Periodicals postage is paid at Denver, Colorado. POSTMASTER: Send address changes to:

$$
\begin{gathered}
\text { Love Publishing Company } \\
\text { Executive and Editorial Office } \\
\text { P.O. Box } 22353 \\
\text { Denver, Colorado } 80222 \\
\text { Telephone (303) 221-7333 }
\end{gathered}
$$

Edward L. Meyen

University of Kansas
Glenn A. Vergason Georgia State University
Richard J. Whelan

University of Kansas Medical Center model of transition, (e) IDEA; (f) the federal School-toCareers initiative; and (g) standards-based reform. These mandatory transition services foreshadowed the development of an integrated academic, social, and vocational curriculum in conjunction with work experience (Halpern, 1992).

\section{Cooperative Workstudy Programs}

Cooperative workstudy programs for students with mild disabilities could be considered a precursor to the present models of transition (Halpern, 1992). Workstudy programs were conducted cooperatively between the public schools and local offices of vocational rehabilitation through formal agreements. Teachers spent half of their time as workstudy coordinators supervising students in community work placements.

Despite the proliferation of this model in the 1960's, it essentially died in the 1970 s, primarily because of flawed funding mechanisms and the "similar benefits" requirement of the 1973 amendments to the Vocational Rehabilitation Act. This requirement stipulated that federal rehabilitation funds could not be used to pay for services that are the responsibility of another agency (in this case, public schools, which now were required by the Education for All Handicapped Children Act (PL 94-142) to provide an appropriate education to all students with disabilities). With passage of PL 94-142, community work experiences were considered part of the student's educational program; therefore, rehabilitation agencies could no longer pay for this service. Schools, however, did not always consider this type of program as a top priority when it was their sole responsibility. Thus, these programs often were discontinued.

\section{Career Education}

The second model that began in the 1970s was the career education movement. The concept of career education was first introduced in 1971 by the U.S. Commissioner of Education at a national conference for secondary school principals (Marland, 1971). Educators were concerned with the high drop-out rates of students who failed to see the relevance of what secondary school programs were teaching (Brolin, 1993). Federal financial backing of career education, along with the formation of the U.S. Office of Career Education in 1974, helped to establish career education at the forefront of public education.

Unlike workstudy programs, career education was more general in focus and implementation. Early career education programs did not address the inclusion of students with disabilities. With increased federal attention and funding during the 1970s, however, the career education movement broadened to include students with disabilities (Isaacson \& 
Brown, 1993). Subsequent federal initiatives assisted states to infuse career education into school curricula for all students so that it would become an integral part of the nation's educational process (Brolin, 1993).

In the early 1980 s, career education programs lost significant ground when the Career Education Implementation Incentive Act was repealed. Federal involvement was intended only as "seed money" to encourage the development and expansion of the movement. The intent was to develop career education models that could be integrated within the general education program. In reality, without the infusion of federal funds, career education program, as a separate educational priority lost ground.

\section{OSERS "Bridge" Model of Transition}

Just 2 years after repeal of the Career Education Implementation Incentive Act, and "one school generation after guaranteeing the right to a free and appropriate education for all children with disabilities" (Will, 1984, p. 1), a new federal transition initiative emerged. This model focused exclusively on the transition of students with disabilities from school to employment. The Office of Special Education and Rehabilitation Services (OSERS) defined transition as:

\footnotetext{
a bridge between the security and structure offered by the school and the opportunities and risks of adult life... . The transition from school to work and adult life requires sound preparation in the secondary school, adequate support at the point of school leaving, and secure opportunities and services, if needed, in adult situations. (Will, 1984, p. 2)
}

The model focused on secondary special education, vocational education, and other school-based services providing the foundation of skills, attitudes, personal relationships, and employer contacts that impact future success. The model is based upon three different types of services offered to students with disabilities upon exit from public school programs:

1. Transition without special services for students with disabilities who make the transition by relying on their own resources or those generic services available to all students;

2. Transition with time-limited services for students with disabilities seeking specialized short-term services to secure employment (e.g., vocational rehabilitation services);

3. Transition with ongoing services for students with severe disabilities who need ongoing support to sustain employment. Unlike the first two methods of transition, this third bridge required major changes to policies and programs because of the unavailability of these services during the early 1980s.

With federal support for the bridge model, secondary and adult programs for students with disabilities were infused with discretionary funding. This funding allowed for the development of many new and innovative models of transition planning and services.

\section{Halpern's Revised Transition Model}

In 1985 Andrew Halpern expanded the OSERS bridge model beyond the focus on the transition from school to employment. His revised model suggested that the goal of transition programs should be to live successfully in the community (i.e., community adjustment). Halpern's emphasis on the outcome of community adjustment required that schools add to the Bridge Model the quality of residential environments as well as the importance of social and interpersonal networks. The expanded focus on all areas of community adjustment considerably enhanced the one-dimensional aspect of the OSERS's transition model.

\section{IDEA 1990 Amendments: Mandated Transition Services}

During the 1980 s the primary tool used to develop transition capacity was federal discretionary funding. Without specific federal mandates, however, the provision of transition services varied widely from state to state (DeStefano \& Wermuth, 1992). The 1990 reauthorization of the Education for All Handicapped Children's Act-now called the Individuals with Disabilities Education Act (IDEA)—addressed these inconsistencies by mandating that transition planning for students in special education begin at age 16, or younger when appropriate. IDEA identified that transition planning must focus on students' postschool outcomes and that these outcomes be achieved through services and supports provided by a variety of agencies, not just the schools.

The 1990 IDEA expanded previous federal special education law regarding how an individualized education program (IEP) was to be developed for a young adult with disabilities. IEPs for students with disabilities who were at least 16 years old were required to include a statement of needed transition services focusing on postschool outcomes (e.g., postsecondary education, vocational training, integrated employment, supported employment, continuing and adult education, adult services, independent living, and community participation), and including interagency linkages if needed. 
Schools were responsible for ensuring that a range of experiences, services, and supports were available to the student so he or she could work toward achieving the desired outcomes. These transition services include instruction, community experiences, the development of employment experiences and other postschool adult outcomes, and, if appropriate, daily living skills and functional vocational assessment. Finally, the IDEA of 1990 required that the transition plan reflect the needs, preferences, and interests of the young adult with disabilities and that it be developed with input from and active participation of the student and family, school staff, relevant adult service agencies, and other community members.

An additional concern the IDEA addressed was the need for interagency linkages between the schools and community agencies. The law stated that other community agencies that may be involved with the student also should be included in the transition planning process.

This meant that schools must develop relationships with community agencies that could provide some of the identified transition services to students with disabilities before and upon graduation from high school. Although the school was not required to provide all of the needed transition services, it was identified as the responsible party for ensuring that the transition services are provided. Therefore, interagency linkages and coordination were considered crucial in providing comprehensive transition planning for students with disabilities.

\section{School-to-Work Opportunities Act of 1994}

In 1994 the School-to-Work Opportunities Act (later known as School-to-Careers) was authorized. The law provides start-up funds to stimulate development of state and local partnerships between business, labor, education, and community-based organizations that would prepare and support youth to enter high-skill careers through coordination of school-based learning, work-based learning, and connecting activities between school and work.

Unlike the Career Education Implementation Incentive Act, the School-to-Work Opportunities Act explicitly includes students with disabilities. The School-to-Work Opportunities Act also is compatible with IDEA because it supports individual planning and coordinated education/ work experiences by 16 years of age or younger to prepare students for positive post-school outcomes, particularly employment.

Some states have used School-to-Work to broaden transition services and make them more inclusive for all students. Other participating state and local partnerships still struggle with whether and how to include students with disabilities, as well as how to move beyond the earlier career education approach to meet the spirit of this initiative. Authorization of the School-to-Work Opportunities Act will end in 2001. Whether reauthorization is likely continues to remain unclear. Moreover, an evaluation of all federal education legislation enacted in 1994 (USDOE, 1999) stresses the need to build more integral relationships between School-toCareers initiatives and states standards-based reform efforts. The School-to-Work evaluation, together with experience gained from the demise of the Career Education Act, raises questions as to whether fledgling School-to-Careers partnerships forged since 1994 will survive if the School-toWork Opportunities Act is not reauthorized in 2001.

\section{Standards-based Reform}

One of the more challenging initiatives of the 1990s for the field of special education is the standards-based reform movement, which began with education reforms in the 1980s and became more focused with passage of Goals 2000: Educate America Act and the Improving America's Schools Act (the reauthorized Elementary and Secondary Education Act) in 1994. Standards-based reform involves alignment of standards, assessments, and accountability systems to provide a coherent framework for curriculum, instruction, personnel development, technology, school finance, integrated services, and virtually every educational activity, to improve student outcomes. Accountability systems linked with standards-based reform tend to tie school accreditation (high-stakes for schools) and graduation (highstakes for students) with student progress on state and local assessments.

The standards-based reform movement seems to have taken root with support from political leaders ranging from governors to chief state school officers. National and international comparisons between the performance of states (e.g., the National Assessment of Educational Progress) and countries (e.g:, the Third International Math and Science Survey) are being used as public agenda-building tools to raise awareness of the need to improve schools and raise expectations for and performance of all students.

When initially authorized, the U.S. Department of Education viewed the School-to-Work Opportunities Act as an essential component of standards-based reform as promoted by Goals 2000 (Riley, 1995). The intent of Goals 2000 was to promote improvement of state and local education systems to ensure that all students leave high school with the necessary skills to succeed in a competitive and rapidly changing global economy. The School-to-Work Opportunities Act was enacted to complement Goals 2000 by ensuring 
that students learn relevant workplace skills and have relevant work experience (Smith \& Scoll, 1995). As described in the previous section, however, the challenge of integrating work experience within the general curricula has not been fully met. Moreover, at this writing most states are just beginning to address the issue of including students with disabilities in standards-based reform.

\section{IDEA 1997 Amendments: Standards and Outcomes}

The 1997 amendments to IDEA reflect the influence of standards-based reform and, like other education legislation from the mid-1990s, the reauthorized IDEA continues to focus on student outcomes. IDEA's transition planning requirements lowered the age of identification of students' transition needs to age 14 and the development and implementation of a transition plan for all students with disabilities starting 16 years of age (or younger, when deemed appropriate).

Now, IDEA also requires that IEPs show how students with disabilities will address state and local standards and how they will participate in state assessments, in keeping with standards-based reform. Clearly, the overall intent of these changes in IDEA is to ensure that students with disabilities will progress toward the same high standards to which other students must achieve and that states' and schools' accountability systems must include students with disabilities.

IDEA clearly specifies that schools must direct attention to outcomes and be responsible for ensuring that a planning process is in place to identify, work toward, and plan for these postschool outcomes. In turn, the effectiveness of these secondary programs may be judged by the success of the students in meeting state and local standards and by their success in postschool life (DeStefano \& Wermuth, 1992; Turnbull, Bateman, \& Turnbull, 1993).

The 1997 reauthorization of IDEA seems to provide the needed leverage to create secondary school reforms that will ensure successful adult outcomes for students with disabilities. The unique aspects of the law that are the impetus for change in schools include:

- developing interagency linkages

- broadening the scope of curricula and programs to include instruction, related services, community experiences, and employment

- increasing performance expectations for students with disabilities in conjunction with standards-based curriculum and holding states and schools accountable for the postschool outcomes students achieve

- involving students, parents and community agencies in the planning process
- changing the role of many school professionals to one of service coordination.

Since the 1960s the term transition has taken on new meaning among professionals and families involved in the field of disabilities. With the advent of federal policy initiatives and mandates, transition now is associated with a specific stage in the life of a young person with disabilities from school to adulthood. This transition has broadened, since the early federal initiatives, from focusing solely on employment to targeting all facets of community integration for persons with disabilities, including residential living, community access, friendships, and recreation.

Many of the federal initiatives and subsequent mandates represent a systematic attempt to resolve the poor economic, social, and educational outcomes for young adults with disabilities. Legislation such as IDEA sets in place minimal compliance requirements for school districts to provide transition planning and services. Clearly, however, without attention to significant exemplary practices in education and secondary school and adult service reform, the impact of transition services on the lives of young adults with disabilities will be minimal. With this in mind, in the next section we review best practices of exemplary transition programs for students with disabilities.

\section{BEST PRACTICES OF \\ EXEMPLARY TRANSITION PROGRAMS}

Over the past decade an abundance of information regarding best practices in transition has proliferated (Halpern, Lindstrom, Benz, \& Nelson, 1991; Kohler, DeStefano, Wermuth, Grayson, \& McGinty, 1994; Patton \& Browder, 1988; Patton \& Dunn, 1999; Rusch \& DeStefano, 1989). Much of the information regarding best practices, however, has not been well substantiated with empirical evidence of improved outcomes (Greene \& Albright, 1995; Johnson \& Rusch, 1993). Kohler (1993) found that only 4 of 11 transition best practices were supported by empirical evidence, primarily through follow-up studies. These practices included: (a) vocational training, (b) parent involvement, (c) paid work, and (d) social skills training. In recent studies seeking to apply a more rigorous criteria of best practices, Kohler and her colleagues have developed a taxonomy of transition practices for students with disabilities (Kohler, 1996, 1998) as well as within the school to work efforts for all students (Kohler \& Chapman, 1999).

While not empirically substantiated, there does appear to be, at minimum, face validity for indicators of effective transition programs (Clark \& Kolestoe, 1995). Table 1 presents 
Table 1

Best Practices in Transition Planning and Services

\section{Best Practice}

Family Network and Involvement

Individualized \& Comprehensive

Transition Planning

Interagency Cooperation and

Collaboration (Including

Business Partnerships)

Focus Curriculum on

Postschool Outcomes

Student Involvement and

Self-Determination

Social Skills Training

VR Counselors in Schools

School-based Related Services

Follow-up Studies and

Program Evaluation

Personnel Preparation

Work Experiences/Job Placement

Integrated Activities in

School and Community

Flexibility in Planning

Availability of Postschool

Adult Services

Administrative Support and

Program Structures

Comprehensive Vocational

Assessment

Identifying and Matching

Environmental Supports

Career Pathways and

Contextual Learning

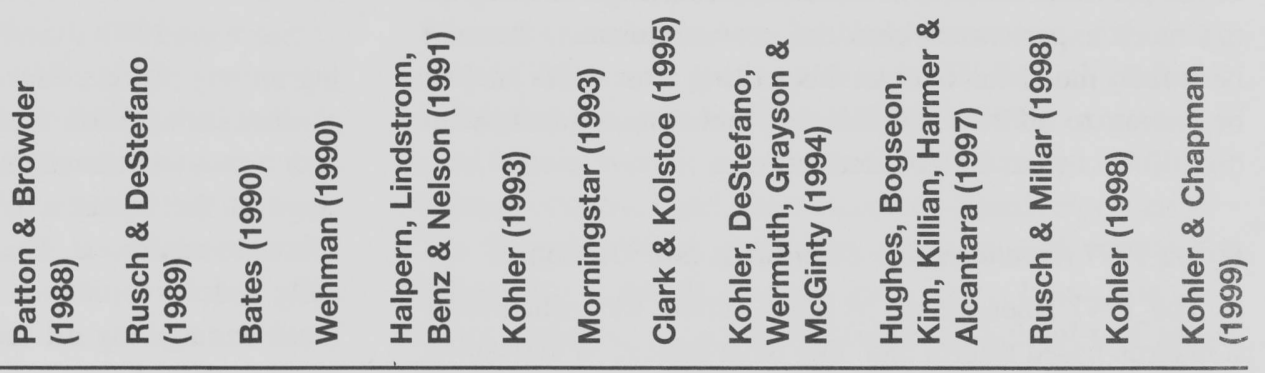

$\bullet \bullet \bullet \bullet \bullet \bullet$

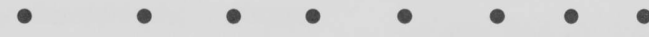

-
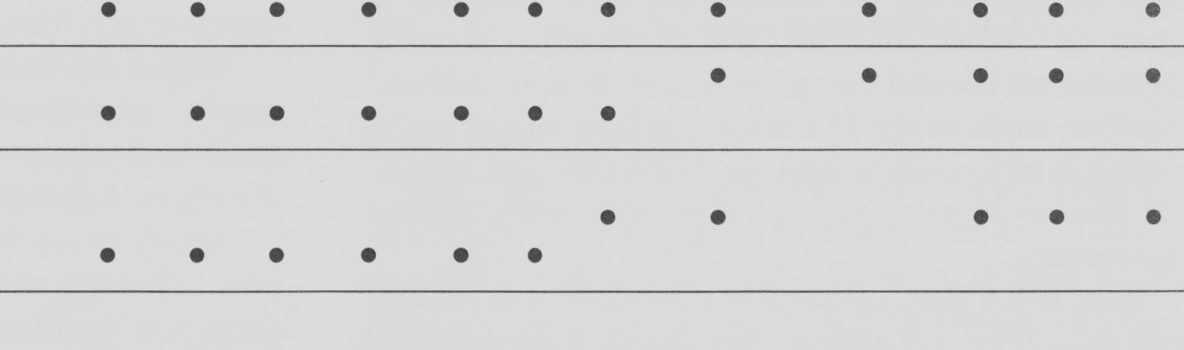

$\bullet \bullet \bullet-\bullet \quad \bullet \quad \bullet$


a summary of several opinion-based and research studies regarding identified best practices of transition programs.

In examining the summary of transition indicators from Table 1, the literature in the field clearly is consistent in identifying certain best practices. The key components identified throughout the literature include:

- a focus on community outcomes when developing curriculum and instruction

- the importance of interagency collaboration both during planning and in formally sharing resources

- the necessity of an individualized method of planning for transition

- the importance of family and support network involvement in planning and decision-making.

Though not consistently identified as a best practice early on, the critical role that student self-determination and student involvement play in transition planning is now considered to be a priority outcome for special education (Ward \& Halloran, 1993). We believe that self-determination is the cornerstone of quality school programs and is intrinsically related to issues of quality of life, as discussed below.

An emerging trend in transition relates to the issues surrounding quality of life for young adults with disabilities. Although "quality of life" has no single definition, attempts have been made to define this term and examine how it relates to service delivery (Dennis, Williams, Giangreco, \& Cloninger, 1993) and transition outcomes (Halpern, 1993; Patton \& Dunn, 1999; Rusch \& Millar, 1998). Halpern (1993) defined quality of life using three basic domains:

1. Physical and material well-being (e.g., physical health, financial security)

2. Performance of a variety of adult roles (e.g., career, leisure, personal relationships, spiritual fulfillment)

3. A sense of personal fulfillment (e.g., happiness, satisfaction and a sense of general well-being).

His preliminary research examined whether relationships exist between objective transition outcomes and these more subjective quality-of-life domains.

Despite his meager research findings, Halpern's recommendations for including quality of life as a focus of transition outcomes include paying attention to these more subjective dimensions and not solely on observable postschool outcomes. He further stressed the importance of focusing on the full array of adult roles that comprise quality of life and developing the instructional strategies to ensure that students with disabilities have the skills and self-determination necessary to achieve these roles.
From the literature and research reviewed, leaders and practitioners in the field seem to agree on what is needed for successful transition programs for students with disabilities. Only within the past few years, however, have researchers begun to examine the relationship between best practices and student outcomes. In fact, Johnson and Rusch (1993) and Sale, Metzler, Everson, and Moon (1991) recommend that future research directions must include an examination of accepted best practices and their impact upon and predictor of successful postschool outcomes for students with disabilities.

\section{STRATEGIES FOR INCORPORATING STUDENT- CENTERED BEST PRACTICES INTO SCHOOL TRANSITION PROGRAMS}

Given our underlying belief that student self-determination must be a foundation of school programs and is tied directly to quality of life, the practice of promoting student involvement and participation clearly must be considered with regard to all transition practices. That is, we would assert that individuals who engage in self-determination have a better quality of life and that the effectiveness of all transition-related practices is related directly to their impact in facilitating self-determination. Thus, we believe that the best practices we have identified as critical for transition are, indeed, "best practices" because of their role in preparing and empowering adolescents and young adults with disabilities to self-determine.

Our point of view is beginning to be supported by emerging empirical data that sends a strong message of the importance associated with practices related to self-determination and student and family involvement in transition planning and service delivery (Kohler, 1996). Therefore, the four components of transition discussed below cannot be considered outside the framework of self-determination.

1. Individualized planning is a central component of self-determination because it focuses on the unique needs and aspirations of the person. However, individualized planning can facilitate self-determination only to the extent that the individual and those closest to him or her are actively involved in the process. Individualized planning that occurs in the third person (i.e., planning for the person) suggests that the person is disenfranchised from decisions about his or her long-term plans.

2. The involvement of family and support networks is at the heart of self-determination because, ultimately, the student's quality of life will depend on his or her ability to realize goals with support from those who are closest. Family 
involvement has emerged as one of the few consistent indicators leading to successful adult outcomes. Certainly, adolescence is a time of tremendous change for young adults and their families, particularly related to issues surrounding the emergence of adult roles and the shift from familydirected decision making to students taking the lead. Students with disabilities, however, continue to seek support and guidance from family members and friends during transition, probably more so than they do professionals. Establishing a network of support may be one of the most important features of transition planning that will ensure success long after the student leaves school.

3. A focus on community outcomes is crucial to selfdetermination in that it takes into account the range of contexts in which an individual will participate and allows the individual to entertain the possibilities for participation through continued learning, living arrangements and lifestyle, recreation, work and career development, and other facets of citizenship. Developing the skills to achieve successful adult outcomes is essential to implementation of transition service. How students receive this instruction should be as varied and diverse as the students themselves and should be offered in a range of settings including school-based programs, community experiences, postsecondary education and training, and through natural supports and extracurricular activities.

4. Interagency collaboration provides a support network to ensure that an individual can participate and achieve the outcomes he or she chooses. The quality of interagency collaboration, however, is linked largely to how well this network supports the individual in accomplishing his or her goals. Services that are arranged or coordinated for the convenience of service providers may have little impact or even pose barriers to self-determination. Strategies to promote self-determination, individualized planning, family and network involvement, community outcomes, and interagency collaboration will be discussed in more detail below.

\section{Self-Determination and Student Involvement in Transition Planning}

Throughout the transition planning process, students should have the opportunity, and be encouraged, to participate and make decisions. Even though students are required to be invited to transition IEP meetings, this alone will not ensure that their preferences and interests will be considered, especially if they have not developed the skills necessary to advocate their preferences. Skill development in selfadvocacy and self-determination must begin early and gradually; the demands and responsibilities can be increased as the student gains competence and matures.
Students who do not possess self-determination might lack the skills necessary to achieve successful adult outcomes (Martin, Marshall, \& Maxson, 1993). Wehmeyer (1992) concluded that the lack of self-determination may be one of the factors leading to the poor postschool outcomes for students with disabilities. Some have argued that the outcome of public school education should be to focus on selfdetermination (Ward \& Halloran, 1993).

To participate fully in their transition planning process, students should be able to advocate for their hopes, needs, and desires without undue influences from others. Although self-advocacy and self-determination sometimes are considered to be the same skill, they actually are complementary skills that enable the student to express and act upon his or her hopes, dreams, and desires.

Self-advocacy can best be described as the expression and fulfillment of one's needs (Phillps, 1990). Once students are able to describe their needs (e.g., the functional limitations of their disability) and request the accommodations needed to enable them to function effectively, they can be considered self-advocates. For instance, a student with a learning disability that affects writing composition should be able to describe what she needs to help her succeed in an English class. Further, the student must have the skills to seek ways to accommodate her disability.

Self-determination can be considered a broader concept that includes student self-advocacy. The three primary components of self-determination are:

\section{Skills \\ 2. Attitudes and motivation \\ 3. The student's social environment.}

Self-determination, therefore, involves more than just having the skills necessary to make decisions and advocate for one's needs. It incorporates the attitudes and motivations regarding one's abilities and opportunities for success. From this perspective, self-determination could be defined as the student's ability to define and achieve goals from a base of knowing and valuing oneself (Martin et al., 1993).

Learning skills for self-determination might be meaningless or even harmful in the absence of a social context that actively supports these skills. Students who are supported to make decisions in school, at home, on the job, and in the community are much more likely to succeed in their adult life. A definition of self-determination that captures this multidimensional perspective is:

Achieving self-determination ... is definitely more than the
sum of its parts. It requires not only that people with dis-
abilities develop inner resources, but that society support 
and respond to these people. Self-determination is a lifelong interplay between the individual and society, in which the individual accepts risk-taking as a fact of life and in which society, in turn, bases an individual's worth on ability, not disability. (Ward, 1988, p. 2)

As students make the transition from high school to adult life, they will be faced with many decisions, most of which begin during the transition planning process. If students are self-determined, they can make those decisions based on their own perceptions of their needs and desires (Wehmeyer, 1998). Therefore, students must have the skills and opportunities to make decisions and to understand the consequences of those decisions. Active participation in the planning process for transition is an excellent way to begin to support students to develop self-determination, but this takes more than their token involvement at an IEP meeting. It is a process that must begin early in life and continue throughout the transition period.

Both school and home can provide rich opportunities for developing the skills, attitudes, and support for selfdetermination. Students must develop these skills, at the latest, when they begin participating in their transition planning process. Preferably, however, self-advocacy and selfdetermination skill instruction begins before the student reaches age 14 .

We recommend that schools prepare their students to participate in the transition planning process and, thus, adult life by initiating a self-determination skill curriculum before students reach secondary school. Many excellent curricula are currently available for students with disabilities to increase their self-determination. Although each curriculum may offer a different approach to the delivery of instruction in self-determination, the main skills taught by selfdetermination curricula include (Morningstar and Lattin, 1996):

1. Student self-awareness. Student should be aware of their strengths, needs, interests, and preferences. Students should understand their disability, learning styles, and accommodations, as well as their legal rights and responsibilities. This self-awareness must lead to increased positive self-esteem and confidence.

2. Problem-solving and decision making. Students should be able to define the problem, gather information and resources, identify pros and cons, make informed decisions, and communicate their preferences.

3. Goal setting. Students should learn the skills to identify their vision and long-range goals, identify all possible resources, develop an action plan to reach these goals, and evaluate the outcomes. Goal setting also includes the ability to take informed risks and to take responsibility for the consequences of their actions.

4. Communication skills. These skills include body image and posture, clearly expressing ideas and feelings, listening to what others have to say, asking questions, planning and organizing thoughts, and accepting comments and criticism.

In addition, most of the self-determination curricula provide opportunities and support for students to use their newly learned skills. Typically these opportunities have focused on student-directed IEPs in which the student takes primary responsibility for developing his or her goals for the IEP and actually running his or her own IEP meetings. In addition, several of the curricula offer strategies for increasing students' involvement in making decisions regarding their employment and future living options, and in social relationships and community participation.

In sum, a main goal of transition planning is to enable young people to assume these rights and responsibilities so they can function and contribute in the adult world as independently as possible. Transition planning provides a way for schools to support students in identifying their goals and developing plans for achieving these goals. This process, especially when it is person-centered, provides an ideal way for students to practice the skills of self-advocacy and decisionmaking that they will utilize throughout life. By way of summary, a final definition of self-determination incorporates the three critical elements of all of the self-determination curricular models (individual skills, intrinsic motivation, and environmental influences):

\begin{abstract}
Self-determination refers to an individual's awareness of personal strengths and weaknesses, the ability to set goals and make choices, to be assertive at appropriate times, and to interact with others in a socially competent manner. A self-determined person is able to make independent decisions based on his or her ability to use resources, which includes collaborating and networking with others. The outcome for a self-determined person is the ability to realize his or her own potential, to become a productive member of a community, and to obtain his or her goals without infringing on the rights, responsibilities, and goals of others (Serna \& Lau-Smith, 1995, p. 144, italics in original).
\end{abstract}

\section{Individualized Planning Methods}

Transition planning for students with disabilities requires that schools develop a method of planning that incorporates long-range planning (focusing on postschool outcomes for students beginning at 14 years of age), as well as short-term 
action steps in the form of the annual individualized education program (IEP). Studies focusing on the transition components of IEPs, however, indicate that the quality of IEPs specific to transition is lacking (Carnine, 1997; Malouf \& Schiller, 1995).

There is increasing concern that transition planning will become an administrative activity designed only to fulfill minimal compliance with the law rather than reflect the preferences and needs of students (Grigal, Test, Beattie, \& Wood, 1997; Smith, 1990; Stowitschek \& Kelso, 1989). National studies of transition sections of IEPs reveal that the statements of needed transition services typically were not individualized to a given student's preferences, interests, and needs; that the desired postschool outcomes seldom reflected exemplary practices; that students routinely did not attend their IEP meetings; and that interagency involvement often was lacking (deFur, Gretzel, \& Kregel, 1994; Lawson \& Everson, 1993).

If the ultimate goal of transition services is to realize the quality of life that Halpern (1993) described, an IEP that includes transition planning cannot be developed unless the student has provided meaningful input. Although the amount and kind of input will vary according to the student's age and capabilities, the student's preferences and interests must be included to the greatest extent possible.

Person-centered planning provides a unique opportunity for the student to be the center of the planning process. Person-centered planning focuses on the student's strengths. It identifies a variety of supports (both formal and informal) that can be combined to achieve family and student dreams. Person-centered planning can be used to enhance and improve the transition process by increasing student and family involvement. Although there is a variety of different strategies for person-centered planning (see Table 2 for a review of five models), all contain similar components of: (a) group support, (b) a positive description of the student, focusing on strengths and preferences, (c) development of a vision for the future, and (d) an action plan for reaching the vision.

1. Facilitating group support. The student and his or her family should decide who will be involved in the person-centered planning process. There are no required group members such as in an IEP meeting. People who know and care about the student and who are committed to supporting the student are the best members. Having a facilitator who is committed to the process, has strong communication skills, is open-minded, and can keep people on task is important. The ratio of professional to nonprofessional members should be equal. Therefore, extended family members, friends, and community members must be included.
2. Creating a positive description. The planning is driven by the student's strengths, interests, and preferences. A description or profile of the individual provides the group with a place to start that is not deficit-driven. This positive description is developed by having the group respond to questions. Examples are: "What has he contributed to his family and community?" "What are his strengths?" "What does he like to do?" Answering these questions provides the group with a positive perspective of the student, as well as a rich source of information from which to develop the vision for the future.

3. Developing a vision for the future. This vision for the future should describe how the student will be fully included in the community-home, school, neighborhood, work. The vision for the future should not be based upon services and supports currently available in the student's community because this might limit the vision. While the vision for the future is positive, the person-centered planning process doesn't ignore obstacles and the realities of service systems, it just focuses on the vision in order to make necessary changes through action planning.

4. Taking Action. The plan of action is developed based upon a dynamic and collaborative problem-solving process. This is where the planning group focuses on the barriers and obstacles to achieving the vision for the future. The action plan that is developed should include what actions will be taken, by whom, and when they will be accomplished. In addition, a critical aspect of the person-centered planning process is that all members of the group are responsible for implementing the action steps so that no one person feels overwhelmed.

Person-centered planning provides a vital role in preparing a student with disabilities to actively participate in the transition planning process. The processes of bringing together the significant persons in a student's life, describing how the student might interact with the community, and envisioning with the future provide both a learning opportunity for the student and family members and help to ground the planning process in the context of the individual student's life and surroundings. Each of these elements of person-centered planning prepare the student, family, and community for the student's achievement of the skills, motivations and supportive contexts to be self-determined.

\section{Involvement of Family and Support Networks}

During the transition from school to adult life, the role of family members has proven to be essential to the success of students with disabilities (Kohler, 1993; McNair \& Rusch, 
Table 2

Overview of Five Person-Centered Planning Methods

\begin{tabular}{|c|c|c|c|}
\hline $\begin{array}{l}\text { Elements of } \\
\text { Person-Centered } \\
\text { Planning } \\
\text { Practices }\end{array}$ & $\begin{array}{l}\text { Group Action } \\
\text { Planning (GAP) }\end{array}$ & $\begin{array}{l}\text { Making Action } \\
\text { Plans (MAPS) }\end{array}$ & $\begin{array}{l}\text { Essential } \\
\text { Lifestyles } \\
\text { Planning (ELP) }\end{array}$ \\
\hline $\begin{array}{l}\text { Creating } \\
\text { Positive } \\
\text { Description } \\
\text { of the Individual }\end{array}$ & $\begin{array}{l}\text { What are 's } \\
\text { preferences? } \\
\text { What are } \\
\text { contributions to } \\
\text { family, friends? } \\
\text { Tell about a time } \\
\text { you shared with } \\
\\
\text { What does } \\
\text { do best? }\end{array}$ & $\begin{array}{l}\text { What is the } \\
\text { person's history? } \\
\text { Who is the } \\
\text { person? } \\
\text { What are the } \\
\text { person's gifts, } \\
\text { strengths, and } \\
\text { talents? }\end{array}$ & $\begin{array}{l}\text { Find out } \\
\text { nonnegotiables, } \\
\text { strong } \\
\text { preferences, and } \\
\text { highly desirables. } \\
\text { People who know } \\
\text { and care about } \\
\text { this person } \\
\text { say ... } \\
\text { (reputation) }\end{array}$ \\
\hline
\end{tabular}

Personal Futures Planning For Planning (PFP) The Future

Construct a personal profile focusing on the

What does student's:

- history

- relationships

- choices

- what works

- what doesn't work

like to do?

With whom?

Where does like to go?

With whom?

What is 's personality like?

What are __ 's strengths and positive contributions to family and community?

\begin{tabular}{|c|c|c|c|c|c|}
\hline $\begin{array}{l}\text { Developing a } \\
\text { Vision for the } \\
\text { Future }\end{array}$ & $\begin{array}{l}\text { What are } \\
\text { the great } \\
\text { expectations } \\
\text { for the } \\
\text { student? }\end{array}$ & $\begin{array}{l}\text { What is the } \\
\text { dream? } \\
\text { What is the } \\
\text { nightmare? } \\
\text { What does the } \\
\text { person need? } \\
\text { What would an } \\
\text { ideal day look like? }\end{array}$ & $\begin{array}{l}\text { Develop a vision } \\
\text { for the future. } \\
\text { What is the } \\
\text { individual's desired } \\
\text { lifestyle? }\end{array}$ & $\begin{array}{l}\text { Discovering a } \\
\text { vision and a plan. } \\
\text { Finding desirable } \\
\text { images of the } \\
\text { future. }\end{array}$ & $\begin{array}{l}\text { Envision the future } \\
\text { and supports for } \\
\text { these areas: } \\
\text { - living } \\
\text { - working } \\
\text { - transportation } \\
\text { - free time } \\
\text { - friends } \\
\text { - education }\end{array}$ \\
\hline Taking Action & $\begin{array}{l}\text { Which people } \\
\text { can create } \\
\text { opportunities for } \\
\text { preferences? } \\
\text { Brainstorm ideas. } \\
\text { Summarize the } \\
\text { steps needed. } \\
\text { Identify timeline. }\end{array}$ & Plan of action. & $\begin{array}{l}\text { If this is going to } \\
\text { happen, we } \\
\text { must... } \\
\text { Identify supports } \\
\text { and people to } \\
\text { provide supports. }\end{array}$ & $\begin{array}{l}\text { Translate vision } \\
\text { into reality. } \\
\text { Identify obstacles, } \\
\text { opportunities, and } \\
\text { specific action } \\
\text { steps. }\end{array}$ & $\begin{array}{l}\text { Prioritize options } \\
\text { and resources. } \\
\text { Develop an action } \\
\text { plan identifying } \\
\text { immediate steps } \\
\text { and those down } \\
\text { the road. } \\
\text { Who, when, } \\
\text { outcome, } \\
\text { evaluation. }\end{array}$ \\
\hline
\end{tabular}


1991; Morningstar, Turnbull, \& Turnbull, 1995). Once a student leaves school, the primary means of support, guidance, and advocacy often becomes the family and the student's support network. Therefore, transition models have begun to develop ways to ensure that students with disabilities have positive support networks prior to leaving school. Some have argued that the best form of "social security" does not come from federal mandates or funding streams but, rather, from the weaving of a fabric of informal supports for individuals ( $R$. Turnbull, personal communication).

This might involve assisting students and their family to think about who they consider to be a part of their informal network (i.e., those outside of formal agencies and service providers) and could or do turn for support and assistance. Then those in the informal support network are brought into the process of planning and supporting individuals as they make the transition from school. This concept includes the involvement of mentors and role models as well.

In general, the potential benefits of family involvement in the education of students with disabilities includes better school attendance, reduced dropout rates, higher test scores, and improvement in student attitudes (Flaxman \& Inger, 1991). Family involvement has been identified as one of the few primary determinants of success during transition (Kohler, 1993; McNair \& Rusch, 1991). In practice, however, parents and professionals often have difficulty in achieving cooperative working relationships (Goldberg \& Kuriloff, 1991; Todis \& Singer, 1991). Despite clear mandates in IDEA for family involvement, research indicates that families too often are relegated to the role of passive participants during transition planning (Hanley-Maxwell, Pogoloff, Whitney-Thompson, 1998).

Several factors, individually and collectively, have been identified in Table 3 as creating barriers to family-professional collaboration. Building meaningful family involvement in transition that requires families and professionals work together to resolve these barriers. Hanley-Maxwell et al. (1998) identified two skills that are key to breaking down barriers to family involvement: (a) learning to listen and (b) inviting support and involvement. These and other solutions are reviewed in Table 3.

Person-centered planning approaches emphasize creating connections among the individual with a disability, nuclear and extended family, professionals, friends, and community citizens. One of the keys of these approaches is for participants to envision great expectations for the future, creatively solve problems, and commit to working together over the long haul. The values inherent in effective person-centered planning are applicable to transition planning and constitute effective ways to listen and invite support (Clark, 1998).
Building meaningful involvement of families and support network members in transition planning requires that schools invite their support and involvement at different stages in the transition process. Wehmeyer, Morningstar, and Husted (1999) have identified several strategies for family involvement that have to be considered during transition assessment, planning, and program implementation.

1. Consider the impact of transition upon the family as a whole rather than just focusing on the student's needs and strengths. By considering the family from a systems perspective, professionals give special attention to how actions of each member affect the family as a whole. Taking this point of view allows professionals to consider issues such as how to involve siblings, extended family members, and parents in the student's transition program; how to gain access to resources and networks of family and friends to help the student live, work, and participate in the community; and how to gauge the impact of this major life transition upon the entire family.

2. Develop processes and tools that will allow professionals to listen to families' needs and expectations. All too often, professionals in their role as "experts" tend toward action without considering or including feedback from families. Family interviews, transition questionnaires, personcentered meetings, transition informational meetings, and written materials are all examples of ways by which professionals can gather information from families. In addition, use of these methods should be ongoing and longitudinal to ensure that changes in family circumstances and needs will be considered.

3. Take into account more than just family members' inclusion at the annual IEP meeting. Families must be prepared to participate as equal members of the planning team. Professionals also should consider how to involve siblings and other extended family members in the transition process as they may be the primary support network for the student once he or she leaves school.

4. Family responsibilities toward transition planning should not be overlooked; however, we need to involve family members at a level and capacity that meet their needs. Specific responsibilities of family members include: dreaming about their child's future; engaging in ongoing communication with school professionals; asking specific questions when needed; supporting student self-determination; supporting school efforts to provide career development and job training; and focusing on student strengths.

5. Professionals' responsibilities toward facilitating family involvement in transition should include: asking families 
Table 3

Barriers and Solutions to Family Involvement in Transition Planning

\section{Barriers to Family Involvement in Transition Planning}

\section{Professional and Family Misperceptions}

Professionals often characterize families as either uninvolved or overly involved in transition planning. Although parents perceived as nonparticipants often give professionals a free hand in transition planning, those who are highly involved often develop a reputation as being difficult. For families, misperceptions range from distrust of, and lack of honesty with, professionals about the family's needs to overreliance on professionals to solve all the problems.

\section{Limited and Conflicting Expectations}

Parental experiences with professionals during transition are often viewed as stressful and negative. Parents' expectations for their child's future can create barriers during transition planning. On the one hand, some families hold limited expectations for their adolescent with disabilities, perhaps in part because of the limited opportunities and services available, particularly for those with severe disabilities. On the other hand, families who want a future for their son or daughter that is different from what service providers are offering may be in conflict with professionals, or viewed as having "unrealistic expectations" when planning for these future adult outcomes.

\section{Lack of Opportunity}

Families often report being left out of the transition planning in any meaningful way irrespective of their desire to be more involved. Typically, when transition planning occurs, it is at a time and place convenient to school professionals, often conflicting with parental work schedules. In addition, family members do not always receive accurate and comprehensive information about transition planning. These families are at a distinct disadvantage when they are involved in planning meetings simply because they lack information.

\section{Strategies to Increasing Family Involvement in Transition}

\section{Role Redefinition}

To achieve collaborative relationships, old assumptions about roles and expectations must change. Professionals should consider the family's point of view and encourage participation at a level that meets the family's needs. In this way, professionals move from the role of "expert" to "partner" with families. In turn, families need to move from a passive "recipient" role to one in which they are considered and supported to be active in the decision-making process. The family's knowledge and experiences with their child should be acknowledged and utilized throughout the planning process.

\section{Provide Information Early and Throughout Transition Planning}

To reduce the stress and uncertainty of transition, families need information about the adult services available in their community. This information should be presented in a way that families can understand, especially related to the differing eligibility requirements of each agency. In addition, families often need to hear the same information more than once from people they know and trust, so communicating with families should begin early and continue throughout the transition years. A successful method of conveying information is to establish parent-to-parent connections so families get information from other families.

\section{Creating New Opportunities to Collaborate}

If transition planning meetings are to meet the needs of students and families effectively, school professionals must reexamine how these meetings operate. Perhaps the most effective elements from person-centered planning and selfdetermination models should be included in transition IEP meetings. In this respect, we would be creating IEP meetings that have as their primary focus the visions of the student and family. IEP meetings would ensure the active participation of students and families and support the development of self-determination in transition planning and implementation.

\section{Developing New Skills}

Taking control of planning might be the most important aspect of transition. Students and families often talk about how transition continues long after school services end. In addition, many students and families continue to be involved in individualized planning meetings as a part of different adult service systems. Therefore, it makes sense that schools develop processes by which families and young adults with disabilities can develop the skills necessary to participate actively as an equally contributing member of their IEP (and future individualized planning) meetings. 
how they want to be involved and respecting this expressed level of involvement; creating comprehensive career development programs that incorporate the role of families; viewing extended family members as potential contributors to transition planning; keeping in mind the lifespan approach to transition; helping families and students to connect with appropriate adult services; and considering the informal support that families and others may be able to provide in transition services.

Families of students with disabilities ultimately are the most vital and constant support and advocacy system available to support student self-determination during transition. As with student participation in planning, families must learn the value of self-determination and how to adjust their roles with the student and community to support the student's ongoing lifestyle decisions.

\section{Community Outcomes}

Early models of transition planning have been expanded from a focus only on employment goals to a more comprehensive view of postschool outcomes (e.g., career development, community living, postsecondary education and training, community participation). The language and intent of IDEA has helped to shift the focus from a narrow to a multidimensional perspective of transition.

A number of problems have been attributed to the narrow interpretation of transition planning, including the tendency to concentrate only on procedural compliance with the law by creating transition documents and procedures that result in a "check-off" or "add-on" approach to transition (Kohler, 1998). These practices have resulted in programs that do not meaningfully prepare students for the movement from school to adult life.

The language within IDEA, however, moves the field to emphasize the student's life aspirations in relation to all educational activities and secondary school programs within which the student participates. Kohler (1998) refers to this point of view as a transition perspective, in which the focus of transition planning is on preparing students to move from school to adult life by identifying postschool goals based upon the students preferences, interests and needs; designing comprehensive instructional activities and educational experiences to promote the attainment of these postschool outcomes; and to work in collaboration with a variety of school-based and community support services. Her definition of a transition-focused school incorporates this broaden perspective:

A transition-focused school would begin early to facilitate student-driven postschool goal setting, align students with

\begin{abstract}
school-day and extracurricular activities, work as a collegial unit that perceives the education of noncollege-bound youths as equally important as that of college-bound youths. . . A transition-focused school is a community of leaders, teachers, counselors, supporting staff, students, and parents that work in concert to ensure that all students develop valued and appropriate postschool goals, participate in schoolbased and community-based curricula, develop academic and other needed skills, and are fully engaged in the process of learning." (Kohler, 1998, p. 189)
\end{abstract}

The emphasis on student adult outcomes, however, can create tension within existing secondary school systems, particularly related to the more comprehensive focus of quality of life and achievement of emergent adult roles, not just a single outcome such as employment or postsecondary education. Ensuring that all students with disabilities plan for and acquire the necessary skills that will enable them to live and work within their communities is a major undertaking for secondary special educators and related services staff. Even as community-referenced programs, curricula, and models have proliferated over the decades, the real challenge facing educators who work with students with disabilities is to integrate these models within secondary programs so the needs of students with disabilities, and in essence all students, are met.

The increased attention to including secondary students with disabilities in the general academic curriculum often does not allow enough time during a student's school day to provide specific needed transition services (e.g., communitybased instruction, independent living skills). The commencement model of deferred graduation programs exemplifies the shift from traditional transition approaches to consumerdriven thinking (Izzo, Johnson, Levitz, \& Aaron, 1998). These programs offer a tremendous opportunity for students who have met their required credits toward graduation but still are in need of transition services or students who typically continue to receive school-based special education services until they are 21.

Commencement programs encourage students to experience the rite of passage of high school commencement with their peers, but continue to receive flexible and individualized transition services from the school district and in conjunction with other adult agencies and services after they meet their graduation requirements (Tashie, Malloy, Lichtenstein, 1998). Students participating in commencement programs do not receive their diplomas at graduation but, instead, continue to work toward needed transition goals and receive transition services as specified in their IEPs, including, when appropriate, the involvement of outside agencies. 
Because these students do not receive a diploma marking the termination of school services and still have unmet needs on their IEPs, they can continue to receive special education services regardless of whether their graduation requirements are met. School districts can continue to receive federal and state reimbursement for these students, as they are still included in the student count. Once students have met all identified transition needs or have aged out of special education services at age 21 , they receive their high school diplomas, thereby terminating special education services.

A unique aspect of commencement models is that they are entirely community-based. Just like students without disabilities, students involved in these models participate in commencement and never return to high school. Instead, these students receive their needed transition services and supports within appropriate community environments. Most commencement programs are based in an apartment, an office in a commercial district, or on postsecondary campuses such as vocational technical schools and community colleges.

Because commencement models are geared to meet students' individual needs, these programs are extremely flexible and eclectic in the provision of services. For example, one student may be learning to do laundry and cook at her own apartment with assistance from the school district and the local independent living center. Another student may be learning how to use the community transportation system with support from the school district while an adult agency serving individuals with developmental disabilities provides his job-coaching supports. Yet another student may be receiving intensive academic support from both the school district and the campus-based disabled services office while attending a postsecondary educational setting.

Most of these commencement programs have been developed for students with severe disabilities and mental retardation who traditionally receive special education services until they reach 21 years of age. Because transition planning requires us to focus on the postschool outcomes for all students with disabilities, commencement programs have expanded to meet the needs of students with disabilities such as learning disabilities, behavior disorders, and mild mental retardation (Olvey \& Thompson, 1997).

\section{Interagency Collaboration}

Students with disabilities, particularly those with significant support needs, need a variety of services and supports once they leave the school setting. Not suprisingly, no one place will meet all of the needs of these individuals. Therefore, a large effort of schools during transition has been to ensure that students with disabilities are connected with outside agencies prior to their leaving school.

The federal regulations under IDEA address the importance of developing interagency linkages for students before they exit from school. The law states that other community agencies that are, or most likely will be, involved with a student should be included in transition planning IEP meetings. This means that schools must develop relationships with community agencies that could possibly serve students with disabilities upon graduation. Schools may even choose to enter into formal interagency agreements for services for students with disabilities prior to their exiting school. Schools, however, cannot force an agency to provide a service, but they must take action if an agency does not provide an agreed-upon service.

School professionals who are involved in transition planning have to be aware of the services available to adults with disabilities. Because schools take the lead in implementing transition planning, teachers and related service staff must be informed about the different agencies they may call upon for assistance. In addition, students and families often rely upon teachers and other school professionals for information about what is available after high school. Finally, schools are responsible for coordinating the planning and services for students with disabilities during transition, and this most likely will include contacting and working with outside agencies.

Facilitating interagency collaboration can be overwhelming if schools do not develop a systematic, multilevel process. Most often, this involves the development of statewide, local, and individualized interagency planning teams (Aspel, Bettis, Quinn, Test, \& Wood, 1999; Rachal, 1996; Halpern, Lindstrom, Benz, \& Nelson, 1991) Statelevel transition teams are composed primarily of statewide policymakers and administrators who focus on evaluating current services and providing fiscal and legislative guidance to local communities (Wehman, Moon, Everson, Wood, \& Barcus, 1988).

Local transition teams provide an organizational structure for helping communities to improve transition services for students with disabilities. Local transition teams consist of school and community professionals, family members, and students and direct their attention to improving school and community transition services within their community. Halpern et al. (1991, p. 1) described the purpose of local transition councils in the following way:

The purpose of the transition council is to discover and implement new and better ways of providing secondary special education and transition services. ... The essence of the transition councils ... is that they function at the local level, 
taking advantage of the unique strengths of their own communities while working to solve common problems.

Local councils often work together to assess, plan, and implement changes in existing services. Most often, the functions they perform include: (a) building and maintaining a team that represents the community; (b) assessing and prioritizing the transition needs of the community; (c) developing and implementing an action plan to address critical needs; (d) providing education, training and employment opportunities for students with disabilities; (e) providing professional development and technical assistance; (f) facilitating interagency collaboration, and the sharing of resources; and (g) monitoring and evaluating team progress (Blalock \& Benz, 1999).

Individual-level teams focus directly on student planning. These teams write the IEP and coordinate the transition planning and services for individual students. This team typically consists of the student, parents, school representatives, and representatives from outside agencies, when a need for services has been identified. Activities typical of this type of interagency team include: (a) ensuring input from students and parents; (b) reviewing all information relevant to the student's present status and future goals; (c) developing the transition IEP that might include interagency linkages and services; and (d) providing additional information as needed (Aspel et al., 1999).

Collaboration between agencies at the state, community and individual level provides a critical context for selfdetermination. Without interagency collaboration, the student is likely to encounter barriers to obtaining services which are essential to successful pursuit of goals and aspirations.

\section{CONCLUSIONS}

As evidenced by the brief chronological review of transition models, federal policy and funding has played, and continues to play, a vital role in stimulating and supporting transition initiatives. Seed funds have served as a catalyst for developing conceptual models for transition and partnerships for implementing these models. We believe, however, that the field of transition is itself experiencing something of a state of transition. That is, catalytic efforts by the federal government to create model transition programs now must provide a basis for program expansion and policy maturation. Systems change is a long-term undertaking; thus, quality transition services must continue to be nourished so they will take root and spread as a regular part of day-to-day practice by special educators, and special educators must learn to connect their efforts to broader initiatives such as
School-to-Careers and other transition programs and standards-based accountability efforts designed to improve outcomes for all students.

The standards-based reform movement, as embodied in the reauthorized IDEA and other legislation, challenges general and special educators to integrate their practices, to hold high expectations for all students, and to build bridges between challenging academic content and applied learning in the workplace. In this respect, the standards-based reform movement poses an important maturational challenge to transition policy. That is, the long-term survival of transition programs and services will depend on how well transition services are integrated into educational practice. Transition services cannot survive as a curricular or instructional addon; rather, they must be integrated with, and acknowledged within, state and national standards-based reform and accountability initiatives.

The emphasis in current legislation such as the Schoolto-Work Opportunities Act and the reauthorization of IDEA reflect a growing awareness of the importance of establishing comprehensive transition systems for all young adults who are leaving our secondary schools for a variety of adult outcomes including employment, postsecondary education and training, independent living, and community participation. The importance of creating a seamless system of secondary educational services for all youths has been an emergent theme both within the field of special education and general educational reform (Johnson \& Rusch, 1993). Rusch and Millar (1998) clarify the challenges facing special and general education systems in the following way:

\footnotetext{
The challenge facing educators is more than just an issue of several professional groups working together in one school. Recent legislation promotes systematic collaboration among professionals at federal, state, and local education agencies. Although this may seem unachievable, it cannot be dismissed or avoided if an effective transition process is to be established for all youth. (p. 54)
}

The field of transition also is moving toward maturation in terms of our understanding of quality practices. We have argued here that self-determination is at the heart of quality of practices and is inextricably related to the quality of life issue raised by Halpern (1993). The goal of facilitating students' self-determination thus becomes a standard for practice for professionals. Quality practices-planning with a focus on community outcomes, family involvement, interagency coordination, involvement of families and support networks, and involvement of students in person-centered planning-build and promote self-determination. 


\section{REFERENCES}

Aspel, N., Bettis, G., Quinn, P., Test, D.W., \& Wood W. M. (1999). A collaborative process for planning transition services for all students with disabilities. Career Development for Exceptional Individuals, 22(1), 21-42.

Bates, P. (1990). Best practices in transition planning: Quality indicators. Carbondale, IL: Transition Project.

Blackorby, J., \& Wagner, M. (1996). Longitudinal postschool outcomes of youth with disabilities: Findings from the national longitudinal transition study. Exceptional Children, 62(5), 399-413.

Blalock, G., \& Benz, M.R. (1999). Using community transition teams to improve transition services. Austin, TX: ProEd.

Brolin, D. E. (1993). Life-centered career education: A competency-based approach (4th ed.). Reston, VA: Council for Exceptional Children.

Carnine, D. (1997). Bridging the research-to-practice gap. Exceptional Children, 63(4), 513-521.

Carter, E., \& McGoldrick, M. (Eds.). (1980). The family life cycle. New York: Garden Press.

Clark, G. M. (1998). Assessment for transition planning. Austin, TX: Pro-Ed.

Clark, G. M., \& Kolstoe, O. P. (1990). Career development and transition education for adolescents with disabilities (2d ed.). Boston: Allyn and Bacon.

Clark, G. M. \& Kolstoe, O. P. (1995). Career development and transition education for adolescents with disabilities ( $3 \mathrm{~d}$ ed.). Boston: Allyn and Bacon.

Council for Exceptional Children. (1994). Statistical profile of special education in the United States, 1994. Supplement to Teaching Exceptional Children, 26, 1-4.

deFur, S., Gretzel, E.E., \& Kregel, J. (1994). Individual transition plans: A work in progress. Journal of Vocational Rehabilitation, 4, 139-145.

Dennis, R., Williams, W., Giangreco, M. F., \& Cloninger, C. J. (1993). Quality of life as context for planning and evaluation of services for people with disabilities. Exceptional Children, 59(6), pp. 499-512.

DeStefano, L., \& Wermuth, T. (1992). IDEA (PL 101-476): Defining a second generation of transition services. In F. Rusch, L. DeStefano, J. Chadsey-Rusch, L.A. Phelps, \& E. Szymanski (Eds.), Transition from school to adult life: Models, linkages, and policy (pp. 537-550). Sycamore, IL: Sycamore Press.

Flaxman, E., \& Inger, M. (1991). Parents and schooling in the 1990s. ERIC Review, 1(3), 2-6.

Goldberg, S. S., \& Kuriloff, P. J. (1991). Evaluating the fairness of special education hearings. Exceptional Children, 57, 546-555.
Greene, G., \& Albright, L. (1995). "Best practices" in transition services: Do they exist? Career Development for Exceptional Individuals, 18(1), 1-2.

Grigal, M., Test, D. W., Beattie, J., \& Wood, W. M. (1997). An evaluation of transition components of individualized education programs. Exceptional Children, 63(3), 357-372.

Halpern, A. (1992). Transition: New wine in old bottles. Exceptional Children, 58(3), 202-211.

Halpern, A. (1993). Quality of life as a conceptual framework for evaluating transition outcomes. Exceptional Children, 59(6), 486-498.

Halpern, A., Lindstrom, L. E., Benz, M. R., \& Nelson, D. J. (1991). Community transition team model: Team leader's manual. Eugene, OR: University of Oregon Press.

Hanley-Maxwell, C., Pogoloff, S. M. \& Whitney-Thomas, J., (1998). Families: The heart of transition. In F. R. Rusch \& J. G. Chadsey (Eds.) Beyond high school: Transition from school to work. (pp. 234-261). Belmont, CA: Wadsworth Publishing.

Hughes, C., Bogseon, H., Kim, J., Killian, D. J., Harmer, M. L., \& Alcantara, P. R. (1997). A preliminary validation of strategies that support the transition from school to adult life. Career Development for Exceptional Individuals, 20,(1), 1-13.

Isaacson, L. E., \& Brown, D. (1993). Career information, career counseling, and career development (5th ed.). Boston: Allyn and Bacon.

Izzo, M. V., Johnson, J. R., Levitz, M., \& Aaron, J. H. (1998). Transition from school to adult life: New roles for educators. In Wehman, P., and Kregel, J. (Eds.), More than a job: Securing satisfying careers for people with disabilities, (pp. 249-286). Baltimore: Paul H. Brookes.

Johnson, J. R. \& Rusch, F. R. (1993). Secondary special education and transition services: identification and recommendations for future research and demonstration. Career Development for Exceptional Individuals, 16(1), $1-18$.

Kiernan, W., McGaughey, M., Lynch, S., Morganstern, D., \& Schalock, R. (1991). National survey of day and employment programs for persons with developmental disabilities: Results from state $M R / D D$ agencies. Boston: Training and Research Institute for People with Disabilities, Children's Hospital.

Kohler, P. (1993). Best practices in transition: Substantiated or implied? Career Development for Exceptional Individuals, 16(2), 107-121.

Kohler, P. (1996). Preparing youth with disabilities for future challenges: A taxonomy for transition programming. In P. D. Kohler (Ed.), Taxonomy for transition 
programming: Linking research and practice (pp. 1-62). Champaign, IL: Transition Research Institute, University of Illinois at Champaign-Urbana.

Kohler, P. (1998). Implementing a transition perspective of education: A comprehensive approach to planning and delivering secondary education and transition services. In Rusch, F., \& Chadsey, J. (Eds), Beyond high school: Transition from school to work (pp. 179-205). Belmont, CA: Wadsworth.

Kohler, P., \& Chapman, S. (1999). Literature review on school-to-work transition [On-line]. Available: www.ed.uiuc.edu/sped/tri/stwpurpose. htm

Kohler, P. A., DeStefano, L., Wermuth, T. R., Grayson, T. E., \& McGinty, S. (1994). An analysis of exemplary transition programs: How and why are they selected? Career Development for Exceptional Children, 17(2), 187-202.

Lawson, S., \& Everson, J. (1993). A national review of statements of transition services for students who are deaf-blind. New York: Helen Keller National Center/Technical Assistance Center.

Malouf, D. B. \& Schiller, E. P. (1995). Practice and research in special education. Exceptional Children, 61(5), 414-424.

Marland, S.P., Jr. (1971). Career education now. Speech presented before annual convention of National Association of Secondary School Principals, Houston.

Martin, J. E., Marshall, L. H., \& Maxson, L.L. (1993). Transition policy: Infusing self-determination and self-advocacy into transition programs. Career Development for Exceptional Individuals, 16(1), 53-61.

McNair, J., \& Rusch, F. R. (1991). Parent involvement in transition programs. Mental Retardation, 29(2), 93-101.

Morningstar, M. E. (1993). Quality indicators of exemplary transition programs. Lawrence: University of Kansas, Department of Special Education.

Morningstar, M., \& Lattin, D. (1996). Student involvement in transition planning (training module). Lawrence: University of Kansas, Department of Special Education.

Morningstar, M., Turnbull, A. P. \& Turnbull, H. R. (1996). What do students with disabilities tell us about the importance of family involvement in the transition from school to adult life? Exceptional Children, 62(3), 249-260.

Olvey, G., \& Thompson, D. A. (1997, November). Colorado Springs' 18-21 Transition Program. Presentation at Department of Special Education, University of Kansas, Lawrence.

Patton, J. R., \& Browder, P. M. (1988). Transition into the future. In B. L. Ludlow, A. P. Turnbull, \& R. Luckasson (Eds.) Transitions to adult life for people with mental retardation: Principles and practices (pp. 3-20). Baltimore: Paul H. Brookes.

Patton, J. R., \& Dunn, C. (1999). Transition from school to young adulthood: Basic concepts and recommended practices. Austin, TX: Pro-Ed.

Peraino, J. M. (1993). Post-21 follow-up studies: How do special education graduates fare? In P. Wehman, Life beyond the classroom: Transition strategies for young people with disabilities (1st ed., pp. 21-70). Baltimore: Paul H. Brookes.

Phillips, P. (1990). A self-advocacy plan for high school students with learning disabilities: A comparative case study analysis of students', teachers', and parents' perceptions of program effects. Journal of Learning Disabilities, 23, 466-471.

Rachal, P. (1996). How state and local interagency partnerships work. HKNC TAC News, 9(1). New York: Helen Keller National Center.

Riley, R. W. (1995). Reflections on Goals 2000. Teachers College Record, 96(3), 380-388.

Rusch, F. R., \& DeStefano, L. (1989). Transition from school to work: Strategies for young adults with disabilities. Interchange, 9(3) 1-2.

Rusch, F. R., \& Miller D.M. (1998). Emerging transition best practices. In Rusch, F.R. \& Chadsey, J.G. (Eds.), Beyond High School: Transition from School to Work (pp. 36-59). Belmont, CA: Wadsworth.

Rusch, F. R., Szymanski, E., \& Chadsey-Rusch, J. (1992). The emerging field of transition services. In F. Rusch, L. DeStefano, J. Chadsey-Rusch, L. A. Phelps, \& E. Szymanski (Eds.), Transition from school to adult life: Models, linkages, and policy (pp. 5-17). Sycamore, IL: Sycamore Press.

Sale, P., Metzler, H. M., Everson, J. M., \& Moon, M. S. (1991, Oct.) Quality indicators of successful vocational transition programs. Journal of Vocational Rehabilitation, pp. 47-63.

Serna, L. A., \& Lau-Smith, J. (1995). Learning with purpose: Self-determination skills for students who are at risk for school and community failure. Interventions in School \& Clinic, 30(3), 142-146.

Smith, S. W. (1990). Individualized education programs (IEPs) in special education-from intent to acquiescence. Exceptional Children 51(1), 6-14.

Smith, M. S., \& Scoll, B. W. (1995). The Clinton human capital agenda. Teachers College Record, 96(3), 389-404.

Stowitschek, J. J., \& Kelso, C.A. (1989). Are we in danger of making the same mistakes with ITPs as were made with IEP? Career Development for Exceptional Individuals, 12(2), 139-151. 
Tashie, C., Malloy, J. M. \& Lichtenstein, S. J. (1999). Transition or graduation?: Supporting all students to plan for the future. In Jorgensen, C. J. (Ed.), Restructuring high schools for all students: Taking inclusion to the next level (pp. 233-260). Baltimore: Paul H. Brookes.

Todis, B., \& Singer, G. (1991). Stress and stress management in families with adopted children who have disabilities. Journal of the Association for Persons with Severe Handicaps, 16(1), 3-13.

Turnbull, H. R., Bateman, D. F., \& Turnbull, A. P. (1993). Family empowerment. In P. Wehman (Ed.), The ADA mandate for social change. Baltimore: Paul H. Brookes.

Turnbull, A., Summers, J. A., \& Brotherson, M. J. (1986). Family life cycle: Theoretical and empirical implications and future directions for families with mentally retarded members. In J. J. Gallagher \& D. M. Vietze (Eds.), Families of handicapped persons: Research, programs, and policy issues, (pp. 25-44). Baltimore: Brookes.

U.S. Department of Education, Office of the Under Secretary, Planning and Evaluation Service. (April 8, 1999). Federal education legislation enacted in 1994: An evaluation of implementation and impact (executive summary) [on-line]. Available: www.ed.gov/offices/OUS/ eval/1994legislation.html

Ward, M. J. (1988). The many facets of self-determination. National Information Center for Children \& Youth with Handicaps: Transition Summary, 5, 2-3.
Ward, M. J., \& Halloran, W. D. (1993, Fall). Transition issues for the 1990s. OSERS News in Print: Transitions, 6(1), 4-5.

Wehman, P. (1990). School-to-work: Elements of successful programs. Teaching Exceptional Children, 23(1), 40-43.

Wehman, P., Moon, M. S., Everson, J. M., Wood, W., \& Barcus, J. M. (1988). Transition from school to work: New challenges for youth with severe disabilities. Baltimore: Paul H. Brookes.

Wehmeyer, M. L. (1992). Self-determination: Critical skills for outcome-oriented transition services. Journal for Vocational Special Needs Education, 15, 3-7.

Wehmeyer, M. L. (1998) Student involvement in transitionplanning and transition-program implementation. In Rusch, F., \& Chadsey, J. G. (Eds.), Beyond high school: Transition from school to work (pp. 206-233). Belmont, CA: Wadsworth.

Wehmeyer, M. L., Morningstar, M., \& Husted, D. (1999). Family involvement in transition planning and implementation. Austin, TX: ProEd.

Will, M. (1984). OSERS programming for the transition of youth with disabilities: Bridges from school to working life. Washington, DC: U.S. Department of Education.

\section{PERMISSIONS AND COPYRIGHT}

All rights are reserved. No part of this publication may be reproduced, photocopied, faxed, stored in a retrieval system, or transmitted in any form or by any means, electronic, mechanical, recording or otherwise, without the prior written permission of the publisher.
Back issues are available for sale. Reproduction requires permission and payment of fees. It is illegal and a violation of federal copyright law to reproduce this publication without permission. Direct all inquiries to the permissions editor. 
INDEX • Volume31

\section{Author Index}

Bullis, Michael (March, 1999)

Butler, Frances M. (September, 1998)

Cheney, Douglas (March, 1999)

Dangel, Harry L. (April, 1999)

De La Paz, Susan (January, 1999)

Gallagher, Patricia A. (October, 1998)

Graham, Steve (November, 1998)

Keel, Marie C. (April, 1999)

Kleinhammer-Tramill, Jeannnie P. (May, 1999)

Lattin, Dana L. (May, 1999)

Lee, Kit-hung (September, 1998)

Lewis, Timothy J. (February, 1999)

Malmgren, Kimber W. (December, 1998)

Miller, Susan P. (September, 1998)

Morningstar, Mary E. (May, 1999)

Owens, Sherie H. (April, 1999)

Roth, Froma A. (November, 1998)

Satter, Linda S. (October, 1998)

Sugai, George (February, 1999)

Troia, Gary A. (November, 1998)

\section{Chronological Index of Titles}

Validated Practices for Teaching Mathematics to Students with Learning Disabilities: A Review of Literature (September 1998)

Promoting a Safe School Environment Through A Schoolwide Wellness Program (October 1998)

An Educator's Guide to Phonological Awareness: Assessment Measures and Intervention Activities for Children (November 1998)

Cooperative Learning as an Academic Intervention for Students with Mild Disabilities (December 1998)

Teaching Writing Strategies and Self-Regulation Procedures to Middle School Students with Learning Disabilities (January, 1999)

Effective Behavior Support: A Systems Approach to Proactive Schoolwide Management (February 1999)

Vocational and Transition Interventions for Adolescents and Young Adults with Emotional or Behavioral Disorders (March 1999)

Selecting Instructional Interventions for Students with Mild Disabilities in Inclusive Classrooms (April 1999)

Using Successful Models of Student-Centered Transition Planning and Services for Adolescents with Disabilities (May 1999) 